UDC 539.4

\title{
Tensile Properties of a Fe-32Mn-6Si Shape Memory Alloy
}

\section{T. Bouraoui, ${ }^{\text {ab }}$ F. Jemal, ${ }^{\mathrm{b}}$ and T. Ben Zineb}

a Institut Préparatoire aux Études d'Ingénieurs de Monastir, Université de Monastir, Monastir, Tunisie

${ }^{\mathrm{b}}$ Laboratoire des Systèmes Électromécaniques, Université de Sfax, Sfax, Tunisie

c Laboratoire d'Énergétique et de Mécanique Théorique et Appliquée, Université de Nancy, Nancy, France

удК 539.4

\section{Характеристики прочности сплава Fe-32Mn-6Si с памятью формы при статических испытаниях на растяжение}

\author{
Т. Бурауи ${ }^{\mathrm{a} . \sigma}$, Ф. Джемал ${ }^{6}$, Т. Бен Зинеб ${ }^{\mathrm{B}}$

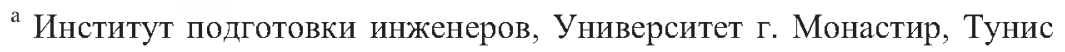 \\ ${ }^{\sigma}$ Лаборатория электромеханических систем, Университет г. Сфакс, Тунис \\ в Лаборатория энергетики и теоретической и прикладной механики, Университет \\ г. Нанси, Франция
}

Исследуются характеристики прочности сплава Fе-32Mn-6Si с памятью формьл при статических испьтаниях на растяжение. Показано, что эти характеристики зависят от температуры, термообработки и микроструктуры материала. Анализируется взаимосвязь прочесса мартенситного превращения с характеристиками прочности и эффектом памяти формы материала, в результате чего предложено одномерное уравнение состояния, описываючее термомеханическое поведение материала при статическом растяжении. Получено хороиее соответствие между результатами численных расчетов и эксперилентальными данными.

Ключевые слова: сплавы с памятью формы на основе железа, характеристики прочности при растяжении, термомеханическое поведение, моделирование.

Introduction. It is well known that shape memory alloys (SMA) are a particular class of materials that can recover a memorized shape by simple heating. This remarkable property, called the shape memory effect (SME), can be exploited in the design of original applications able to bring interesting answers to problems encountered in various industrial fields.

In addition to the classical non ferrous alloys (Ni-Ti- and $\mathrm{Cu}$-based alloys), iron-based SMA have attracted much attention recently due to their low cost, high mechanical strength and good formability [1-7].

In Fe-Mn-Si-based shape memory alloys system, the parent phase, face centred cubic austenite $(\gamma)$, transforms to hexagonal $(\varepsilon)$ martensite by the formation and overlap of stacking faults. The martensite can be reversed to parent austenite on annealing, and this imparts the SME $[1,2]$. 
A wide range of experimental works have been carried out in order to characterize metallurgical properties and thermomechanical behavior of ironbased shape memory alloys [1-7]. But, works dealing on their behavior modeling, necessary to the optimization of their performance and application design are still at an embryonic stage.

Tensile properties are fundamental benchmarks for development of new materials and essential input material parameters for numerical modeling in order to design applications. For this reason, we present in this paper a study of iron-based SMA thermomechanical behavior in tensile. The adopted alloy is the $\mathrm{Fe}-32 \mathrm{Mn}-6 \mathrm{Si}$ which is considered as a good reference of the iron-based SMA. The purpose of this paper is to report the effect of heat treatments and temperature on tensile behavior. The relationship of martensitic transformation, tensile properties and shape memory effect are also discussed. Finally, we propose a macroscopic one-dimensional constitutive law able to describe the thermomechanical behavior in tensile.

Experimental Procedure. The studied SMA in this work was obtained from Aubert \& Duval Company [4]. The alloy was supplied as $18 \times 18 \mathrm{~mm}$ swaged bars and $1373 \mathrm{~K}$ water quenched. The chemical composition (in wt.\%) of this polycrystalline alloy is given in Table 1 .

$\mathrm{T}$ a b 1 e 1

Chemical Composition of Studied Alloy

\begin{tabular}{|c|c|c|c|}
\hline $\mathrm{Fe}$ & $\mathrm{Mn}$ & $\mathrm{Si}$ & $\mathrm{C}$ \\
\hline Balanced & 31.6 & 6.45 & 0.018 \\
\hline
\end{tabular}

This composition is considered as the reference of iron-based shape memory alloys. The $6.45 \%$ of silicon rate is an optimal value leading to a weak stacking fault energy favorable to the reversibility of $\gamma(F C C) \rightarrow \varepsilon(H C P)$ martensitic transformation [5].

Tensile samples were cut by electroerosion machining a long the bar direction. The shape and dimensions of samples are given in Fig. 1.

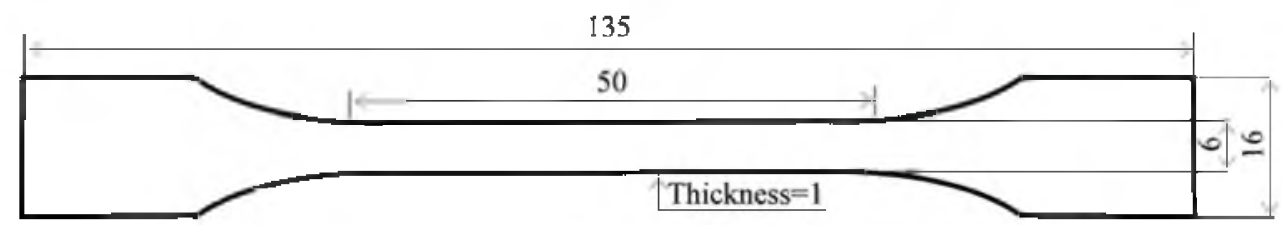

Fig. 1. Shape and dimensions (in $\mathrm{mm}$ ) of tensile samples.

The tensile tests are performed on an MTS machine using a load cell with maximum capacity of $5 \mathrm{kN}$ and an extensometer with a gauge length of $50 \mathrm{~mm}$. Strain rate was fixed at $2 \cdot 10^{-4} \mathrm{~s}^{-1}$.

X-ray diffraction analysis was performed using a Philips diffractometer using monochromatic $\mathrm{Cu}$ radiation $(\lambda=0.15405 \mathrm{~nm})$. 
1. Influence of Heat Treatment on Tensile Properties. The X-ray diffraction pattern of the as-received $\mathrm{Fe}-32 \mathrm{Mn}-6 \mathrm{Si}$ shape memory alloy (Fig. 2) shows a presence of $(10 \overline{1} 0)_{\varepsilon}$ and $(10 \overline{1} 1)_{\varepsilon}$ peaks corresponding to martensite $\varepsilon(H C P)$ phase in addition to (111) ${ }_{\gamma}$ and $(200)_{\gamma}$ peaks corresponding to austenite $\gamma(F C C)$. The mixed $F C C-H C P$ structure is due to the heat treatment performed after the material processing.

When the sample is maintained at $873 \mathrm{~K}$ during one hour and then water cooled at room temperature, the alloy presents an austenitic structure as illustrated by the X-ray diffraction pattern of Fig. 3. After this heat treatment, the transformation temperatures determined by electrical resistance measurements are specified in Table 2 [4].

T a b 1 e 2

Transformation Temperatures (in K)

\begin{tabular}{|c|c|c|c|}
\hline$M_{s}$ & $M_{f}$ & $A_{s}$ & $A_{f}$ \\
\hline 270 & 215 & 385 & 395 \\
\hline
\end{tabular}

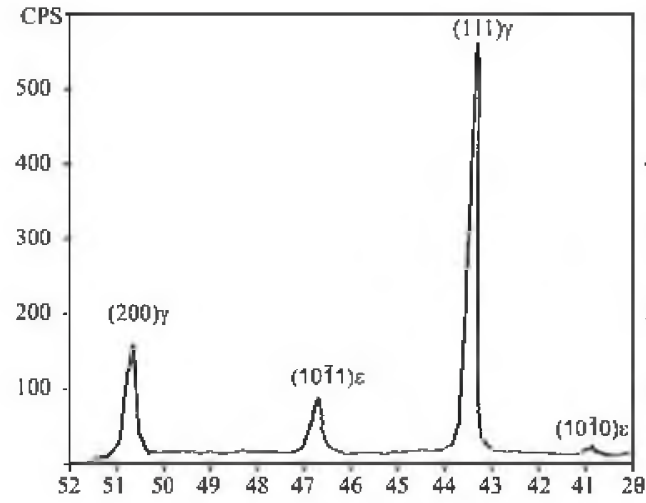

Fig. 2

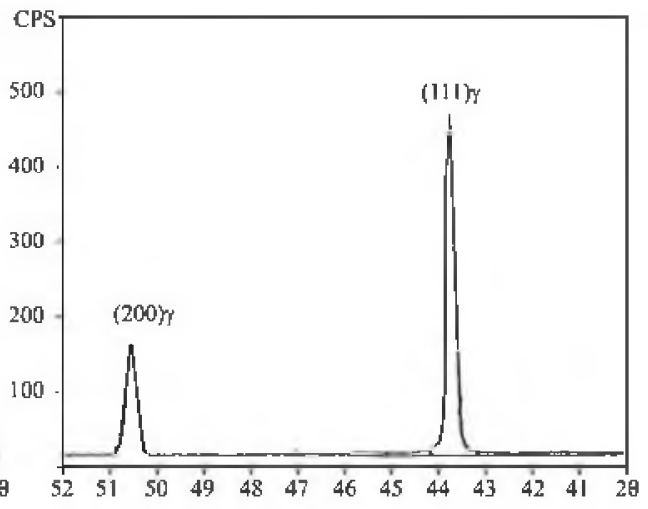

Fig. 3

Fig. 2. X-ray diffraction pattern of as-received Fe-32Mn-6Si alloy.

Fig. 3. X-ray diffraction pattern of Fe-32Mn-6Si alloy after reference heat treatment.

Tensile properties depend on the heat treatment and the structure of the material. Figure 4 presents tensile tests relating to the as-received and after austenitization heat treatment states.

A detailed analysis of Fig. 4 curves is given in Table 3.

According to the results of the tensile tests of Fig. 4 and the mechanical properties summarized in Table 3, we can deduce that the presence of thermal martensite in the initial state is at the origin of yield strength increasing and the reduction of ductility. Thermal martensite tends to strength the matrix. On the other hand, the ultimate tensile strength is slightly higher when the initial state is austenitic. We will further see than even in this case tensile behavior is controlled by the martensitic transformation. For iron-based shape memory family, one of the favourable factors to a good shape memory effect is the absence of the thermal martensite at operating temperature. Pre-existing $\varepsilon$ martensite suppresses the 
stress induced martensite transformation to a certain extent due to $\varepsilon$-plates intersections [6]. On the basis of this report, the heat treatment which conferred on alloy an austenitic state at room temperature will be regarded as a reference heat treatment.

$\mathrm{T}$ a b 1 e 3

Mechanical Characterictics of Fe-32Mn-6Si Alloy

\begin{tabular}{|c|c|c|c|}
\hline State of material & $\begin{array}{c}\text { Yield strength (0.2\%). } \\
\text { MPa }\end{array}$ & $\begin{array}{c}\text { Ultimate tensile } \\
\text { strength, MPa }\end{array}$ & $\begin{array}{c}\text { Elongation } \\
\text { to fracture, \% }\end{array}$ \\
\hline As-received & 230 & 695 & 20 \\
\hline After heat treatment & 190 & 710 & 27 \\
\hline
\end{tabular}



Fig. 4. Stress-strain curves for as-received and after heat treatment Fe-32Mn-6Si alloy samples

2. Stress Induced Martensite and Shape Memory Effect. The curve of the Fig. 5 represents tensile behavior of $\mathrm{Fe}-32 \mathrm{Mn}-6 \mathrm{Si}$ alloy after the heat treatment of austenitization. The general shape of the stress-strain curve is similar to that observed in traditional metallic materials but inelastic strains are induced by matrensitic transformation and plastic gliding. During tensile loading, the $\gamma \rightarrow \varepsilon$ martensitic transformation occurs starting from a critical stress. According to X-ray diffraction pattern (Fig. 5b), the sample becomes a mixture of $\gamma$ and $\varepsilon$ after a deformation of $4.5 \%$ followed by an unloading. The critical stress inducing martensite is difficult to determine with precision on the experimental curve. Conventionally, this stress is given to $0.2 \%$.

The observed non-linear behavior during unloading is related to the pseudoelasticity phenomenon. This phenomenon cannot be explained solely by the conventional idea of transformation pseudoelasticity observed in usual SMA (Ni-Ti- and $\mathrm{Cu}$-based alloys), since the testing temperature is lower than $A_{s}$ and the martensitic transformation is semi-thermoelastic (or non-thermoelastic). The pseudoelasticity of $\mathrm{Fe}-\mathrm{Mn}-\mathrm{Si}$-based alloys was reported in other works [7]. The interpretation of this property was possible in terms of the reversible motion of the $\gamma / \varepsilon$ interfaces and/or of twin positions in the austenite. 


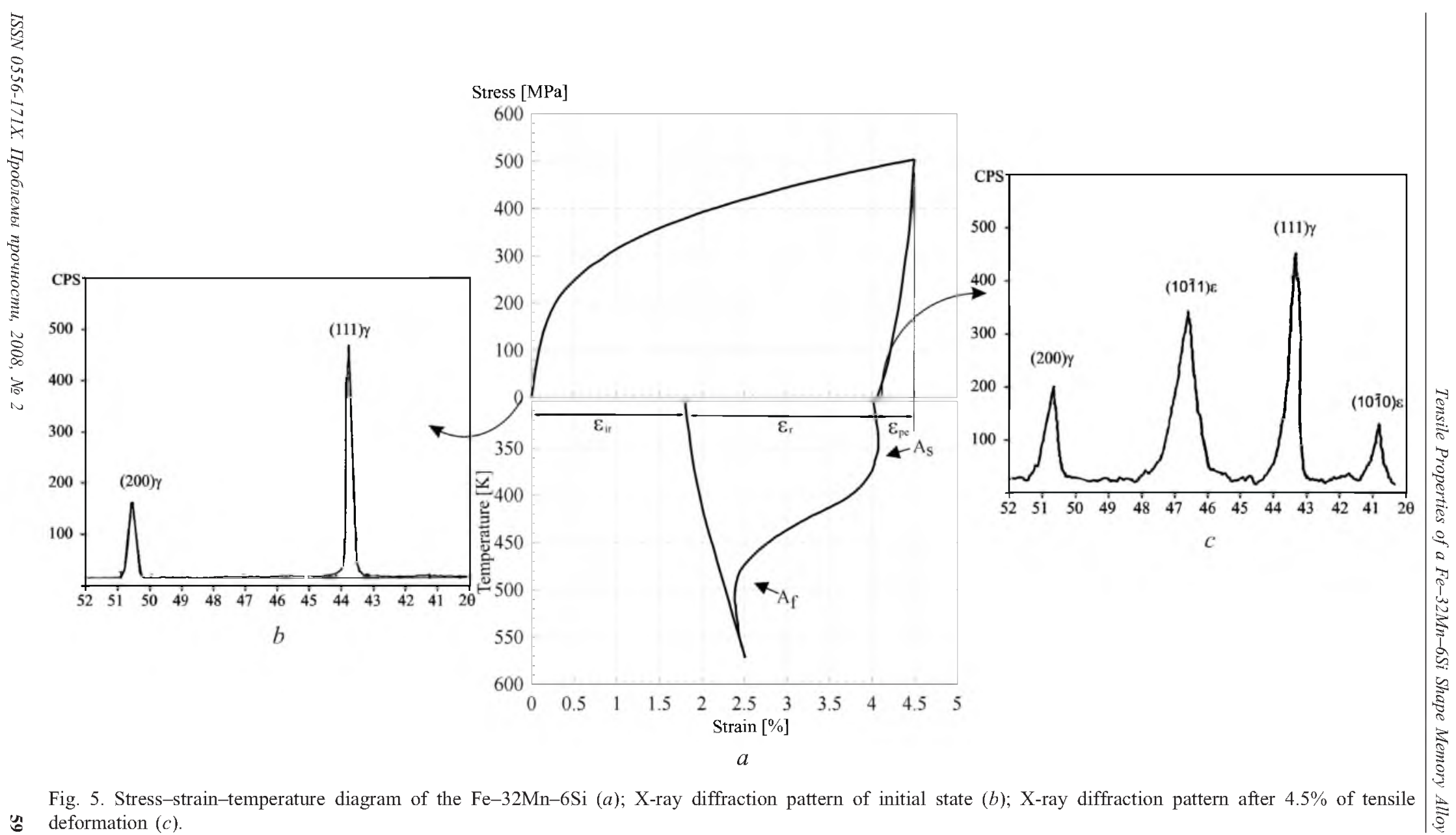


The shape recovery, observed in the temperature-strain diagram (Fig. 5a), is induced by $\varepsilon \rightarrow \gamma$ transformation through the reversion motion of the $1 / 6<112>$ Shockley partial dislocations in the $F C C$ structure by a heating to a temperature higher than $A_{f}$.

The shape recovery rate is defined as

$$
r=\frac{\varepsilon_{p e}+\varepsilon_{r}}{\varepsilon_{p e}+\varepsilon_{r}+\varepsilon_{i r}}
$$

where $\varepsilon_{p e}, \varepsilon_{r}$, and $\varepsilon_{i r}$ are pseudoelastic, reversible, and irreversible strains, respectively.

In the case of the test presented in Fig. 5, the shape recovery is equal to $60 \%$.

3. Tensile Properties at Different Temperatures. Figure 6 shows the stress-strain curves of the $\mathrm{Fe}-32 \mathrm{Mn}-6 \mathrm{Si}$, which were drawn up at different testing temperatures and with maximum prestrain limited to $3.5 \%$. It can be seen that the stress curves exhibit remarkably different characters at the testing temperatures. Of these curves we determine yield stress $(0.2 \%)$ which corresponds, according to the test temperature, at the beginning of the martensitic transformation or the slip in austenite. The critical stresses relating to the various temperatures are deferred in the graph of Fig. 7.

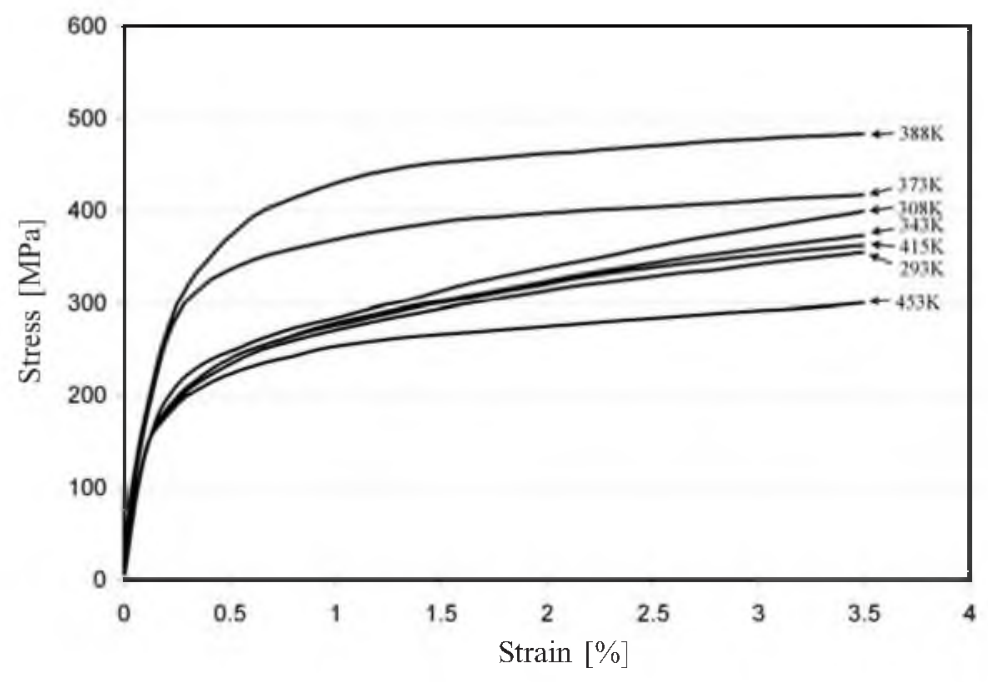

Fig. 6. Stress-strain curves at different temperatures.

On the graph of Fig. 7, we also placed $M_{s}, A_{s}, A_{f}$, and $M_{d}$ temperatures. The latter, which corresponds to the limit temperature of strain-induced martensite, was obtained for experiments at approximately $435 \mathrm{~K}$.

Based on results presented in Fig. 7, two temperature ranges are highlighted. The first is characterized by a transformation straight line with positive slope ( $1 \mathrm{MPa} / \mathrm{K})$, between $M_{s}$ and $M_{s}^{\sigma}$, and where the martensitic transformation precedes the plastic gliding in austenite. The obtained martensite in this case is known as stress-induced martensite. The second is characterized by a plastic 
strain straight line with negative slope $(-0.9 \mathrm{MPa} / \mathrm{K})$, between $M_{s}^{\sigma}$ and $M_{d}$, and where the plastic gliding in austenite precedes a possible martensitic transformation. The martensite which could be formed in this case is called straininduced martensite. For temperatures lower then $M_{s}$, we already saw previously that the presence of thermal martensite tends to strength the matrix and could inhibit the martensitic transformation.



Fig. 7. Temperature dependence of critical stresses corresponding to martensite formation and slip deformation.

On the basis of all these observations, we can conclude that in order to generate stress-induced martensite without introducing slip strain in austenite, essential condition to have the best possible SME, the operation temperature must be slightly higher than $M_{s}$.

In addition, the fact that temperature $M_{s}^{\sigma}$ is lower than $A_{f}$, explains the absence of superelasticity such as that observed in usual SMA. It is impossible to be in the configuration where the temperature is higher than $A_{f}$ and the mechanical loading induces the martensitic without slip in austenite. On the other hand, it is possible to observe a weak and partial superelasticity if the temperature of the test is between $A_{f}$ and $M_{d}$.

Based in these experimental observations, a one-dimensional thermomechanical constitutive law is developed. It describes the effect of inelastic strain induced by martensite transformation on the iron-based SMA behavior for tensile loading. The next paragraph presents the thermodynamic formulation leading to this constitutive law.

4. Modeling of Tensile Behavior. The modeling of the thermomechanical behavior of iron-based shape memory alloys is little treated in bibliography. Goliboroda et al. [8] presents a study based on a phenomenological approach.

The suggested model in this work is based on a simplified micromechanical approach in order to lead to macroscopic description $[9,10]$. To determine the behavior of an initial representative volume element (RVE) of austenite, Gibbs energy, $\Psi$, was considered. 
The thermodynamic potential associated to the martensitic transformations is a function of the control variables $(\Sigma, T)$, and the internal variables related to the martensitic transformation.

The Helmholtz energy, noted $\Phi(\Sigma, T)$, is defined between two states: (austenite) and (austenite + martensite). This energy is composed in a chemical energy ( $\left.W_{\text {chemical }}\right)$, elastic energy due to the elastic strain $\left(W_{\text {elastic }}\right)$ and interface energy $\left(W_{\text {interface }}\right)$

$$
\Phi(\Sigma, T)=W_{\text {chemical }}+W_{\text {elastic }}+W_{\text {interface }}
$$

The Gibbs free energy is written as the difference between the potential energy $\left(W_{\text {potential }}\right)$ and Helmholtz energy

$\Psi(\Sigma, T)=W_{\text {potential }}-\Phi(\Sigma, T)=W_{\text {potential }}-W_{\text {chemical }}-W_{\text {elastic }}-W_{\text {interface }}$.

The interface energy can be neglected. This approximation is justified by the metallographic observations revealing a martensite in the form of fine plates [11].

The chemical energy $\left(W_{\text {chemical }}\right)$ can be described as a linear function of temperature and macroscopic volume fraction of martensite, $f$, without any stress dependence

$$
W_{\text {chemical }}=B\left(T-T_{0}\right) f,
$$

where $T_{0}$ denotes the thermodynamic equilibrium temperature between austenite and martensite and $B$ is a material constant.

The total strain is decomposed into an elastic strain and a transformation strain by neglecting the thermal expansion and the plastic gliding in austenite if the maximum strain is about $2.5 \%$ [5]

$$
E=E^{e}+E^{t}=\frac{\Sigma}{E_{Y}}+f \bar{\varepsilon}^{t}
$$

where $E^{e}, E^{t}, \bar{\varepsilon}^{t}$, and $E_{Y}$ indicate, respectively, the elastic strain and the transformation strain, the main strain transformation describing in an averaged way the martensite orientation, and the Young modulus of the alloy whose elastic behavior is assumed to be isotropic and linear. By taking into account the Eq. (4), the potential energy expression is written as

$$
W_{\text {potential }}=\Sigma E=\Sigma\left(E^{e}+E^{t}\right)=\frac{\Sigma^{2}}{E_{Y}}+\Sigma \bar{\varepsilon}^{t} f .
$$

The expression of elastic energy takes into account, in an averaged way, interactions between grains (strain incompatibilities between grains) and between martensite variants (compatibilities inside grains):

$$
W_{\text {elastic }}=\frac{1}{2} \frac{\Sigma^{2}}{E_{Y}}+\frac{1}{2} H\left(\bar{\varepsilon}^{\dagger} f\right)^{2}+\frac{1}{2} A f^{2},
$$


where $A$ and $H$ are material parameters representing respectively the intergranular and intragranular interactions. This expression is derived from a micromechanical formulation by considering, in an averaged way, the effect of incompatibilities between and inside grains [11]. The combination of the different energy expressions leads to the new expression of Gibbs free energy as a function of control and state variables and equally material parameters describing elasticity and martensitic transformation:

$$
\Psi\left(\Sigma, T, f, \bar{\varepsilon}^{t}\right)=\frac{1}{2} \frac{\Sigma^{2}}{E_{Y}}+\Sigma_{\bar{\varepsilon}}^{t} f-\frac{1}{2} H\left(\bar{\varepsilon}^{t} f\right)^{2}-\frac{1}{2} A f^{2}-B\left(T-T_{0}\right) f .
$$

In the continuation, we are interested primarily in the transformation stress. The reorientation stress is neglected because it is assumed that in iron-based SMA only an oriented martensite is active. The driving transformation stress, $F_{m}$, is obtained by deriving energy from Gibbs compared to the martensite volume fraction $f$ :

$$
F_{m}=\Sigma \varepsilon^{t}-B\left(T-T_{0}\right)-H\left(\bar{\varepsilon}^{t}\right)^{2} f-A f .
$$

Let's consider $F_{c}$ a nonzero constant which characterizes the critical transformation stress. This stress is given from the Eq. (8) for $T=M_{s}, \sigma_{0}=160 \mathrm{MPa}$ and $f=0$ (yield transformation)

$$
F_{c}=\sigma_{0} \bar{\varepsilon}^{t}-B\left(T-T_{0}\right)
$$

When $F_{m}<F_{c}$, the yield transformation is not reached yet and we observe an elastic behavior obeying to the Hooke law $\Sigma=E_{Y} E$.

The martensitic transformation starts and progresses until the end of transformation when $F_{m}=F_{c}, \dot{F}_{m}=0$, and $f \leq f_{\text {saturation }}$.

The combination of the Hooke's law with coherence rule $\left(\dot{F}_{m}=0\right)$ makes it possible to lead to the constitutive law of the SMA. The material parameters of $\mathrm{Fe}-32 \mathrm{Mn}-6 \mathrm{Si}$ alloy at $293 \mathrm{~K}$ are given in Table 4.

$\mathrm{T}$ a b 1 e 4

Material Parameters for Fe-32Mn-6Si Alloy at 293 K

\begin{tabular}{|c|c|c|c|c|c|c|}
\hline$E_{Y}, \mathrm{MPa}$ & $T_{0}, \mathrm{~K}$ & $B, \mathrm{MPa} / \mathrm{K}$ & $F_{C}, \mathrm{MPa}$ & $A, \mathrm{MPa}$ & $H, \mathrm{MPa}$ & $\bar{\varepsilon}^{t}$ \\
\hline 135,000 & 340 & 0.016 & 4.2 & -0.88 & 7760 & 0.02 \\
\hline
\end{tabular}

The numerical simulation based on the described model is represented on Fig. 8. The comparison between the experimental curve and the numerical simulation shows overall a good agreement for 3\% prestrain. However, the observed difference is due to the fact that, even for prestrain lower than $3 \%$, the martensitic transformation is accompanied, locally, by a slip deformation in austenite. This behavior, specific to the nonthermoelastic martensitic transformation, tends to disappear with thermomechanical cycling. 




Fig. 8. Comparison between experimental and theoretical curves at $T=293 \mathrm{~K}$.

Conclusions. The mechanical tensile behavior of Fe-32Mn-6Si shape memory alloy is conditioned by $\gamma(F C C) \leftrightarrow \varepsilon(H C P)$ martensitic transformation and depends on temperature and microstructure.

In order to generate stress-induced martensite without introducing slip deformation in austenite, essential condition to have the best possible SME, the operated temperature must be slightly higher than $M_{s}$. In addition, for iron-based shape memory alloys, the fact that temperature $M_{s}^{\sigma}$ is lower than $A_{f}$, explains the absence of superelasticity.

The tensile behavior is described while following the thermodynamic driving forces which are obtained by deriving Gibbs energy with respect to the internal variable martensitic volume fraction.

The comparison between numerical simulation and the experimental results shows a good agreement when permanent strain is about $3 \%$. However, for more significant strains, it would be necessary to take into account, in the theoretical formulation, the plastic slip which occurs in austenite.

Acknowledgments. Part of this work was realized in the framework of Cooperation University Joint Committee between France and Tunisia (CMCU Program No. 04S1117). The authors extend their gratitude to their financial support.

\section{Резюме}

Досліджуються характеристики міцності сплаву $\mathrm{Fe}-32 \mathrm{Mn}-6 \mathrm{Si}$ п пам'яттю форми при статичних випробуваннях на розтяг. Показано, що ці характеристики залежать від температури, термообробки та мікроструктури матеріалу. Аналізується взаємозв'язок між процесом мартенситного перетворення i характеристиками міцності та ефектом пам'яті форми матеріалу, в результаті чого запропоновано одновимірне рівняння стану, яке описує термомеханічну поведінку матеріалу при статичному розтязі. Отримано хорошу збіжність між результатами числових розрахунків і експериментальними даними. 
1. A. Sato, E. Chishima, K. Soma, and T. Mori, "Shape memory effect in $\gamma \rightarrow \varepsilon$ transformation in Fe-30Mn-Si alloy single crystal," Acta Metall., 30, 11771183 (1982).

2. A. Sato, E. Chishima, Y. Yamaji, and T. Mori, "Orientation and composition dependencies of SME in Fe-Mn-Si alloys," Acta Metall., 32, 539-547 (1984).

3. T. Y. Hsu, "Prediction of martensitic transformation start temperature $M_{s}$ in Fe-Mn-Si shape memory alloys," Mater. Sci. Forum, 327-328, 199-222 (2000).

4. T. Bouraoui, K. Tamarat et B. Dubois, "Variations de la résistivité électrique associées aux transformations martensitiques dans l'acier à mémoire de forme FM30," J. Phys. III, 6, 831-841 (1996).

5. J. H. Yang and C. M. Wayman, "Development of Fe-based shape memory alloys associated with face-centred cubic-hexagonal close-packed martensitic transformation," Metall. Trans., 32A, 1445-1154 (1992).

6. A. Sato, K. Soma, and T. Mori, "Hardening due to pre-existing $\varepsilon$-martensite in an Fe-30Mn-1Si alloy single crystal," Acta Metall., 30, 1901-1907 (1982).

7. O. Matsumura, T. Sumi, N. Tamura, et al., "Pseudoelasticity in an Fe-28Mn6Si-5Cr shape memory alloy," Mater. Sci. Eng., 279A, 201-206 (2000).

8. I. Goliboroda, K. Rusinko, and K. Tanaka, "Description of a Fe-based shape memory alloy thermomechanical behavior in terms of the synthetic model," Comput. Mater. Sci., 13, 218-226 (1999).

9. B. Peultier, T. Ben Zineb, and E. Patoor, "Modeling of the martensitic phase transformation for finite element computation," J. Phys. IV , 115, 351-359 (2004).

10. B. Peultier, T. Ben Zineb, and E. Patoor, "Macroscopic constitutive law of shape memory alloy thermomechanical behavior. Application to structure computation by FEM," Mech. Mater., 38, 510-524 (2006).

11. K. Tamarat, V. Stambouli, T. Bouraoui, and B. Dubois, "Structural study of Fe-Mn-Si and Fe-Mn-Cr shape memory steels," J. Phys. IV, C4, 347-353 (1991). 